\title{
Contamination of Escherichia coli 0157:H7 in Dairy Cow Farms
}

\author{
Rachmawati F, Ariyanti T \\ Indonesian Research Center fo Veterinary Science (IRCVS), \\ Jl. RE Martadinata No. 30, Bogor 16114
}

(receiced: 23-10-2017; revised: 27-11-2017; accepted 18-12-2017)

\begin{abstract}
ABSTRAK
Rachmawati F, Ariyanti T. Kontaminasi bakteri Escherichia coli O157:H7 pada peternakan sapi perah. JTTV 22(4): 205-211. DOI: http://dx.doi.org/10.14334/jitv.v22i4.1674

Bakteri E.coli O157:H7 adalah foodborne pathogen yang membahayakan kesehatan manusia. Ternak sapi merupakan reservoir utama dari bakteri ini. Bakteri E.coli O157:H7 yang keluar dari ternak kemudian dapat mengkontaminasi lingkungan sekitar, produk susu, daging, tanaman sayur-sayuran ataupun buah, sehingga dapat berperan sebagai sumber infeksi dan mengakibatkan penyakit pada manusia. Penelitian ini dilakukan untuk identifikasi adanya kontaminasi bakteri E.coli $0157:$ H7 pada peternakan sapi perah sehingga diketahui situasinya terkini. Pengambilan sampel untuk penelitian ini adalah peternakan sapi perah di wilayah Depok, Cianjur, Sukabumi dan Bandung. Jenis sampel yang diambil yaitu ulas dubur sapi atau feses segar dan air minum ternak. Isolasi bakteri E.coli dilakukan pada media mTSB, MacConkey Agar, Eosin Methylene Agar. Identifikasi bakteri sebagai E.coli O157:H7 dilakukan dengan uji biokimia dan untuk penetapan serotipe digunakan uji agglutinasi menggunakan antiserum monospesifik untuk O157 dan H7. Hasil penelitian memperlihatkan bahwa sampel kotoran dan air minum sapi dari seluruh peternakan sapi perah yang diteliti telah terkontaminasi oleh bakteri E.coli. Dari 178 sampel yang diuji telah diidentifikasi sebanyak $126(70,8 \%)$ sampel diantaranya mengandung bakteri E.coli. Dari jumlah 126 sampel yang mengandung bakteri E.coli, ternyata sebanyak $94(74,6 \%)$ adalah bakteri E.coli serotipe O157:H7. Keberadaan kontaminan bakteri E.coli O157:H7 pada peternakan sapi perah, potensi dampaknya bagi kesehatan manusia, serta upaya pencegahan dan pengendalian bakteri ini dibahas dalam tulisan ini.
\end{abstract}

Kata Kunci: Sapi Perah, E. coli, E. coli O157:H7, Lingkungan

\begin{abstract}
Rachmawati F, Ariyanti T. Contamination of Escherichia coli O157:H7 in dairy cow farms. JITV 22(4): $205-211$. DOI: http://dx.doi.org/10.14334/jitv.v22i4.1674

E. coli serotype O157:H7 is a foodborne pathogen that endangers human health. Cattle are the main reservoir of this bacterium. E. coli $\mathrm{O} 157: \mathrm{H} 7$ that come out of the livestock can contaminate the surrounding environment, dairy products, meat, vegetable or fruit crops, so it can act as a source of infection and disease in humans. This research was conducted to identify the contamination of E. coli $\mathrm{O} 157: \mathrm{H} 7$ on dairy cow farms so the current situation is known. Sampling area for this research was dairy cow farm in Depok, Cianjur, Sukabumi, and Bandung. Types of samples taken are cow anal swab or fresh feces and livestock drinking water. Isolation of E. coli bacteria was done on mTSB media, agar MacConkey, and Eosin Methylene Agar. Identification of bacteria as E. coli O157:H7 was done by biochemical test and for serotype determination was used agglutination test using monospesifik antiserum for $\mathrm{O} 157$ and $\mathrm{H} 7$. The results of research showed that of the total 178 samples had $126(70.8 \%)$ samples containing E. coli bacteria. Of the 126 samples containing E. coli bacteria, 94 (74.6\%) were determined as E. coli serotype O157:H7. The presence of E. coli O157:H7 contaminants on dairy cow farms, their potential impacts on human health, prevention and control of the disease is discussed in this paper.
\end{abstract}

Key Words: Dairy Cow, E. coli, E. coli O157:H7, Environment

\section{INTRODUCTION}

Escherichia coli (E. coli) is a bacterium that lives normally in the digestive tract of animals and humans.
E. coli is one of the bacteria belonging to the family of Enterobacteriaceae in the form of a straight, single, paired or short chain rod, measuring 2.0-6 $\mu \mathrm{m}$ in length and $1.1-1 \mu \mathrm{m}$ in diameter. This bacterium is a Gram- 
negative, motile or non-motil, aerobic or anaerobic facultative group. E. coli bacteria were first discovered by Theodore Escherich in 1885 (Scheutz \& Nancy 2005).

E. coli $\mathrm{O} 157: \mathrm{H} 7$ is one of the E.coli serotypes belonging to the pathogenic Enterohaemorrhagic Escherichia coli (EHEC) group. The cow is an EHEC reservoir, and the bacteria can contaminate the environment as well as its contacts with feces. This bacteria is associated with outbreak of foodborne pathogen and sporadic cases in humans in the world (Karmali et al. 2010; Rangel et al. 2005).

The typical symptoms of EHEC infection in livestock and humans are bloody diarrhea. Bleeding diarrhea as a results from verotoxin or Shiga Like Toxin (SLT) produced by EHEC, especially serotype O157:H7. This serotipe was first isolated in 1982 in the United States, during an outbreak of haemorrhagic colitis (HC) in Oregon and Michigan (Bonardi et al. 1999). This serotype is often called verotoksigenik $E$. coli (VTEC). Verotoksin is extracellular, neurotoxic and immunogenic (Ball et al. 1994; Pirro et al. 1995). Human EHEC infection results in haemorrhagic colitis (HC) and haemolytic uremic syndrome (HUS) were also reported (Konowalchuk et al. 1977). Since it was first isolated, the EHEC infection that caused an outbreak of food poisoning was reported as a result of consuming milk, beef, vegetables and fruits contaminated by E. coli O157:H7. In the United States the disease is the second order after Salmonella infection (CDC 1997; Karmali 1989; Hara-Kudo et al. 2000).

In Canada, there was human HUS case as a result consumption of milk in a dairy farm in Canada in 1986. The E. coli O157:H7 was isolated from young cow feces in that dairy farm. Other studies showed that $E$. coli $\mathrm{O} 157: \mathrm{H} 7$ has been isolated from faecal samples from 16 head of cattle or calves and 1 dairy cow from 22 farms, 1 calf from fattening cattle; 2 samples of beef, and 1 milk sample (Wells et al. 1991). Bonardi et al. (1999) reported that the VTEC O157 strain was isolated from faecal samples collected from one of the slaughterhouses in Northern Italy, faecal samples from 59 head of cows, faecal sample from 450 cows of 133 farms, 37 cows from 223 fattening places, 22 from 137 dairy cows that were derived from 60 farms.

In Indonesia, the presence of EHEC bacteria was reported in dairy calves in Bandung, Sukabumi, Cianjur, and Bogor, with symptoms of bloody diarrhea. The bacteria were identified belong to the VTEC 0157 group that lyses vero cells (Kusmiyati \& Supar 1998), However no further identification whether the bacteria as serotype O157:H7. Suwito (2009) identified the presence of this E. coli O157:H7 in milk samples from dairy cow farms in Bogor, Sukabumi and Cianjur districts. Other studies reported that E. coli $0157: \mathrm{H} 7$ was detected as bacterial contamination of beef, fresh milk, pasteurized milk, crabs, white shrimp, bottled water and refills (Sartika et al. 2005; Suardana et al. 2007; Kandau 2009; Marlina et al. 2009. Aryanti \& Maryam (2015) also reported that of 120 samples consist of meat, fresh milk, beef meatballs, beef jerky, sausage, abon, UHT milk, yoghurt and cheese, 39 (32\%) of those contained E. coli O157:H7. Suardana et al. (2016) reported $5(8.6 \%)$ of 58 samples of cow feces in seven villages in Kecamatan Petang, Kabupten Badung, Bali were positive for E. coli O157:H7.

This research was conducted to identify the contamination of E. coli $\mathrm{O} 157: \mathrm{H} 7$ bacteria on dairy cow farms so the current situation is known to minimize risk to human health.

\section{MATERIALS AND METHODS}

\section{Bacteria of reference}

Bacteria used as a reference in this study were $E$. coli O157:H7 ATCC 43984.

\section{Collection of samples}

Samples, swab of anal or fresh feces and drink water of cow, were collected from dairy farms in Depok, Cianjur, Sukabumi and Bandung areas of West Java Province. The feces were taken using sterile cotton swabs and then were inserted into a sterile bottle containing bacto pepton water (transport medium). Sample of drinking water was taken from the pot and put it in sterile plastic bag. All samples were stored in an ice box and transported to the Bacteriolgy Laboratory, IRCVS Bogor.

\section{Isolation and identification of $E$. coli}

Isolation of E. coli $\mathrm{O} 157: \mathrm{H} 7$ followed the procedure of BSN (2008) with modification, i.e 1 gram of feses, or $1 \mathrm{ml}$ of cattle drinking water added with $9 \mathrm{ml}$ mTriptic Soy Broth (mTSB) which was added Novobiocin, then incubated for \pm 24 hours at $37^{\circ} \mathrm{C}$. Furthermore, the culture was grown on MacConkay Agar or Eosin Methylene Blue (EMB) agar medium at $37^{\circ} \mathrm{C}$ for \pm 24 hours. The alleged colony of $E$. coli will indicate lactose or pinkish pink fermentation on MacConkey media Agar or metallic green in EMB. Furthermore, Gram staining is done, planted it in identification media such as Triple Sugar Iron (TSIA), semisolid media / motility test and Indol test, Methyl Red, Voges Prouskauer, Simmon's Citrate (IMViC). After the bacteria was identified as E.coli, the culture was subsequently grown on Sorbitol MacConkay Agar (SMAC) added with Cefixime-Tellurite selective supplementation according to Oxoid Microbiology 
Product procedure, then incubated at $37^{\circ} \mathrm{C}$ for $16-20$ hours. Confirmation of serotype E. coli O157: H7 was performed by serotyping it using a monospecific 0157 and H7 antiserum (Bonardi et al. 1999; Barrow \& Feltham 2003).

\section{Serotyping isolates as $\mathrm{E}$. coli $\mathrm{O157:H7}$}

All of the isolated E.coli were examined by agglutination test using monospecific $\mathrm{O} 157$ and a monospecific $\mathrm{H} 7$ antiserum produced from previous studies (Supar et al. 1988). All E. coli isolates were grown on Nutrient Agar (NA) medium and incubated at $37^{\circ} \mathrm{C}$ for \pm 24 hours were then suspended with a physiological $\mathrm{NaCl}$ solution with turbidity equivalent to Mc Farland No. 10. Furthermore, the bacterial suspension was heated to a temperature of $100^{\circ} \mathrm{C}$ for 2 hours or at $121^{\circ} \mathrm{C}$ for 1 hour, then cooled and checked with a monospecific antiserum 0157. Agglutination test was carried out by means of twenty microliters of E. coli antigen (sample) mixed with $20 \mu \mathrm{L}$ monospecific $\mathrm{O} 157$ antiserum. The agglutination occure within 1-3 minutes in the form fine clumps like sand.

As for examination of somatic antigen $\mathrm{H} 7$, all $E$. coli isolates were grown on a semisolid medium in a tube equipped with a craigic tubes and were incubated at $37^{\circ} \mathrm{C}$ for \pm 24 hours. Bacterial cells grown outside the craigic tube were grown onto NA medium and incubated at $37^{\circ} \mathrm{C}$ for \pm 24 hours. By using a sterile ose, the culture of $E$. coli on NA medium was taken and placed it on the glass object, then it was added with 20 $\mu \mathrm{L}$ sterile aquades and mixed it with $20 \mu \mathrm{L}$ monospesifik $\mathrm{H} 7$ antiserum for agglutintaion test. The agglutination occurs within 1-3 minutes.

\section{Statistical analysis}

Data of microbes identified, percentage and its distribution was descriptively analyzed.

\section{RESULTS AND DISCUSSION}

The results of sample collection from dairy cow farms and summary of laboratory testing is presented in Table 1.

To identify contamination status of dairy cow farm with the E. coli O157:H7, West Java Province was used for sample collection since the population of dairy cattle in this area is high enough, ie $122.811(22.5 \%)$ of total population 545.000 head of dairy cattle in Indonesia (DGLAH 2017).
Biochemical examination of the bacteria isolated from samples (feces and drinking water) grown on the media for Eosin Methylene Blue and IMViC showed that $126(70.78 \%)$ of 178 samples containing $E$.coli. Number percentage of $E$. coli isolated in feces samples was around $40.40-85.18 \%$, while E.coli in drinking water of cow was from $11.11-100 \%$. (Table 1). The E.coli contamination was found in all dairy cow farm located in all location under studied.

Confirmation test of the $E$. coli isolated into O157:H7 serotype using O157 and H7 monospesific antiserum showed that $94(74.6 \%)$ of $126 \mathrm{E}$. coli isolates were positive as O157:H7. Distribution of location contaminated by E. coli O157:H7 serotype and its percentage can be seen in Table 1, indicating that all locations were contaminated by the microbe.

Off the total E. coli serotype O157:H7 isolated, $1.06 \%$ (1/94) of E. coli $\mathrm{O} 157: \mathrm{H} 7$ isolate was from the original faecal samples of dairy cow farms in Depok; as much as 20.2\% (19/94) of E. coli O157:H7 isolates were from faecal samples of dairy cow farm in Cianjur; $2.12 \%$ (2/94) of E.coli $\mathrm{O} 157: \mathrm{H} 7$ isolate were obtained from drinking water sample of dairy cow farm in Cianjur, and as much as $34 \%(32 / 94)$ isolate E. coli O157:H7 obtained from faecal sample of dairy cow farm in Sukabumi, and $1.06 \%(1 / 94)$ isolate E. coli O157:H7 obtained from drinking water of dairy cow farm. Isolates of E. coli O157:H7 obtained from the Bandung area were $31.9 \%$ (30/94) of faecal samples and $1.06 \%$ (1/94) of the drinking water in the farm.

The number and percentage of E. coli $\mathrm{O} 157: \mathrm{H} 7$ identified from $E$. coli isolated from the feces samples of its size varied between $14.28-100 \%$ (Table 1, Figure $1)$. While in drinking water for livestock on farms the contamination may reach $100 \%$ (Table1, Figure 2).

In this study, the percentage of E. coli $\mathrm{O} 157: \mathrm{H} 7$ identified in dairy farms is quite high from faecal samples. In drinking water of the dairy cow the microbes extracted from $100 \%$ of the farms. This data may indicate that majority of dairy cow farm in Indonesia seem to be infected with $E$. coli $\mathrm{O} 157: \mathrm{H} 7$.

Based on the results of this study, shows that all dairy cow farm in all location has been found the existence of $E$. coli $0157: \mathrm{H} 7$, both in feces and drinking water of dairy cow. E. coli $\mathrm{O} 157: \mathrm{H} 7$ found in the feces potentially may contaminate the environment around farms, such as drinking water pot, equipment, soil, grass, milk udders, milk, other healthy cow, or technician who operate the pens, or the farmer and family member itself, so that horizontal transmission can occur. 
Table 1. Results of isolation of E.coli and its identification as E.coli O157:H7 derived from dairy cow farm in the research areas

\begin{tabular}{|c|c|c|c|c|c|c|c|}
\hline \multirow[b]{2}{*}{$\begin{array}{l}\text { Areas/ } \\
\text { Location }\end{array}$} & \multirow[b]{2}{*}{ Farm } & \multirow[b]{2}{*}{ Kind of Sample } & \multirow[b]{2}{*}{ Number } & \multicolumn{4}{|c|}{ Laboratory Results } \\
\hline & & & & $\begin{array}{c}\text { Number } \\
\text { Positive } \\
\text { E.coli }\end{array}$ & $\% *$ & $\begin{array}{l}\text { Number Positive } \\
\text { E.coli O157:H7 }\end{array}$ & $\% * *$ \\
\hline Depok & Dairy Cow & Feces & 10 & 7 & 70.0 & 1 & 14.28 \\
\hline \multirow{2}{*}{ Cianjur } & Dairy Cow & Feces & 47 & 19 & 40.4 & 19 & 100 \\
\hline & & Drinking water & 7 & 2 & 28.57 & 2 & 100 \\
\hline \multirow{2}{*}{ Sukabumi } & Dairy Cow & Feces 9 & 54 & 46 & 85.18 & 32 & 69.56 \\
\hline & & Drinking water & 9 & 1 & 11.11 & 1 & 100 \\
\hline \multirow{2}{*}{$\begin{array}{l}\text { Bandung } \\
\text { (Lembang) }\end{array}$} & Dairy Cow & Feces & 50 & 39 & 78.00 & 30 & 76.92 \\
\hline & & Drinking water & 1 & 1 & 100 & 1 & 100 \\
\hline Total & & & 178 & 126 & 70.78 & 94 & 74.60 \\
\hline
\end{tabular}

* Percentage from number of samples

**Percentage of positive E. coli

The presence of E. coli $\mathrm{O} 157: \mathrm{H} 7$ bacteria in dairy cow feces may also contaminate milk produced by the cow. The milk contaminated with bacteria is very dangerous when consumed by people, when processing of milk is not perfect. The problem of food poisoning caused by drinking milk contaminated with $E$. coli O157:H7 has been reported in Indonesia (Tulung Agung, Bandung and Surabaya) in September 2004 (Kompas 2004). CDC (2007) reported 4 residents in Washington infected by E. coli O157: H7 previously becouse they consumed raw cow's milk in December 2005.

Feces of cattle contain E. coli $\mathrm{O} 157: \mathrm{H} 7$ and then used it as agricultural fertilizer has great potential to pollute agricultural land and vegetables. As Khandaghi et al. (2010), stated that cow feces are commonly used as fertilizer on agricultural land to be the source of the spread and transmission of E. coli $\mathrm{O} 157: \mathrm{H} 7$ due to direct contact or consume unprocessed agricultural produce. From a total sample of 282 soil and vegetable samples such as lettuce, cabbage, carrots and radishes, showed 5 soil samples $(1.77 \%)$ and one vegetable sample $(0.35 \%)$ contaminated with E. coli $\mathrm{O} 157: \mathrm{H} 7$ bacteria confirmed by multiplex PCR technique.

Ruminants are a natural host of E. coli O157:H7, and adult animals infected by the microbe do not show clinical symptoms. Animals infected by the disease after recovery will become a career. Younger animals are more sensitive than adults. Cow as the main reservoir E. coli $\mathrm{O} 157: \mathrm{H} 7$ for humans. Although this bacteria can be isolated from other animals with subclinical symptoms, but it is pathogenic for humans. Infected cattle with E. coli $\mathrm{O} 157: \mathrm{H} 7$ can excrete these bacteria in a short time or in a long time. E. coli O157:H7 can be transmitted through fecal-oral. The spread can be in direct contact between animals, through water resources, feed, or grassland (OIE 2008; CFSPH 2016). Stanford et al. (2005) mentioned that the incidence of mastitis in cow in dairy farms increased due to contamination of E. coli $\mathrm{O} 157: \mathrm{H} 7$ contained in the feces of infected cows. So it can be mentioned that cow feces is the main source of contamination of E. coli $\mathrm{O} 157: \mathrm{H} 7$ in the environment. Feces of cow as the main source of pollution should be feces waste water flowed into the river, because it can pollute the environment with a wider area. This is very dangerous for humans and other animals. It is possible to have faecal effluent on dairy farms with remote locations with water sources.

The high percentage of E. coli O157:H7 in farms due to poor sanitary management of the stable. These bacteria in cows do not show clinical symptoms but are pathogenic in humans. So that its existence will have the potential to spread to the environment around the farm and the possibility of infecting very large other animals and even humans. Although there have been no reports of human illness due to the infection of $E$. coli O157:H7, it has been reported that this bacteria was isolated from humans undergoing dialysis due to kidney failure in Jakarta. While Karawang district, E. coli O157: H7 was isolated from patients with diarrhea symptom (Ariyanti 2016).

Prevention of the spread of $E$. coli $\mathrm{O} 157: \mathrm{H} 7$ bacteria needs to be done, to prevent the occurrence of foodborne disease in humans. Control of E. coli O157:H7 infection can be applied along the food chain from pre-harvest to post-harvest. Strategy on preharvest can be done by reducing the shedding of E. coli O157.H7 in livestock, especially ruminants or by increasing cow resistance against infection of $E$. coli 
Number of E.coli O157: H7 identified from E.coli isolated from feces

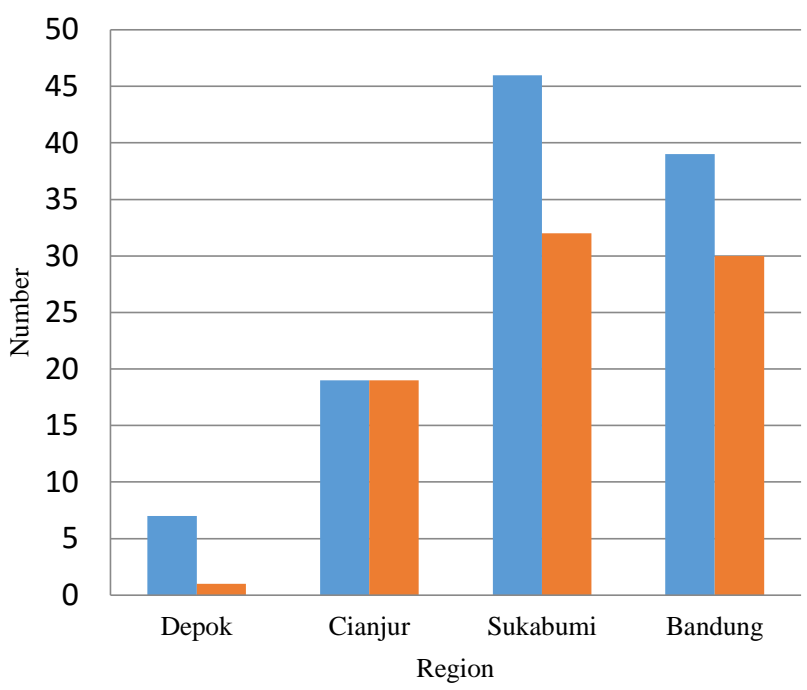

- Positive of E.coli

Positive of E.coli O157:H7

Figure 1. The number of E.coli $\mathrm{O} 157: \mathrm{H7}$ identified from E.coli isolated from feces

Number of E.coli O157: $\mathrm{H} 7$ identified from E.coli isolated from drinking water

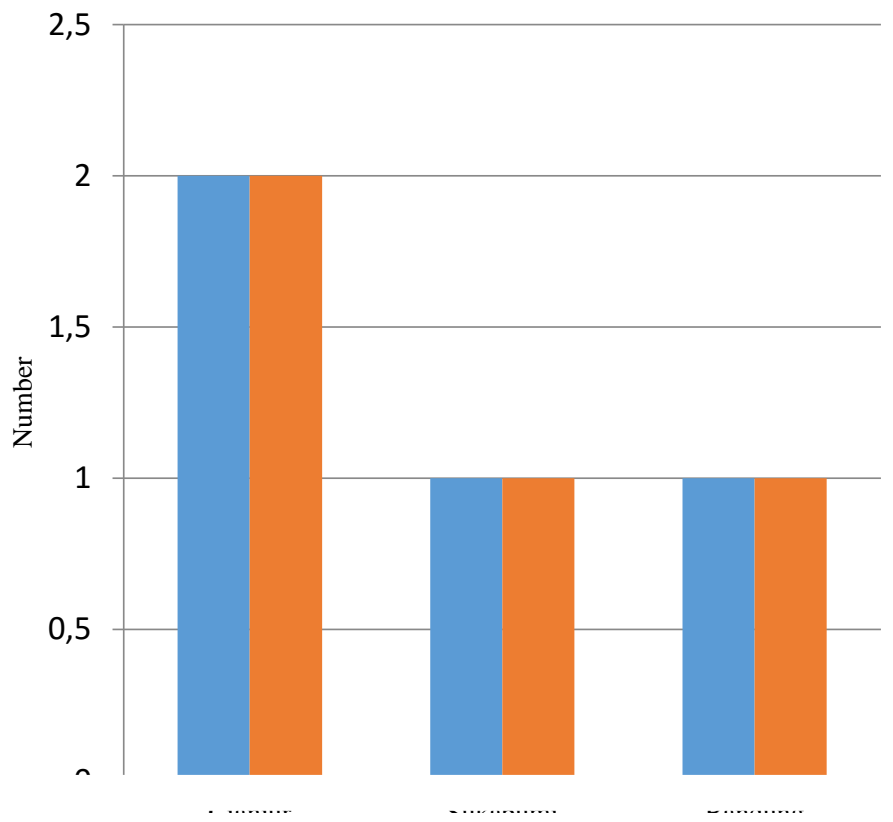

Figure 2. Number of E.coli $\mathrm{O} 157: \mathrm{H} 7$ identified from E.coli isolated from drinking water

O157:H7 on ruminants in farms correlates with reduction of carcass contamination by the microbe in slaughterhouses. This step shows that interventions at the pre-harvest stage are important and effective in controlling foodborne infection in humans (Ayscue et al. 2009; OIE 2008). The strategy of shedding control in cattle is still being developed (OIE 2008).

\section{CONCLUSION}

The fairly high percentage of dairy cow farm contamination with pathogenic E.coli O157:H7 have been identified in this studied. This information may indicate that major protion of dairy cow farms could be contaminated by these bacteria. When the bacteria 
found in the feces, the bacteria may found also in drinking water of cattel in the farms. The presenst $E$. coli $\mathrm{O} 157: \mathrm{H} 7$ in the cow farm has a potential risk to human health through contamination to wider environments such as soil, grass, drinking water source (well), pons, ditch, vegetables, or fruits planted in surrounding contaminated cow farm areas. Prevention and control of E.coli O157:H7 infection should always be promoted such as improvement management of animal health and healthy culture in the community. Further research needs to be done is to test the sensitivity of microbes to antibiotics.

\section{REFERENCES}

Aryanti T, Maryam R. 2015. Deteksi Escherichia coli O157:H7 pada pangan asal ternak dan olahannya dengan teknik IDAS-ELISA. Noor SM, Handiwirawan E, Martindah E, Widiastuti R, Sianturi RG, Herawati T, Purba M, Anggraeny YN, Batubara A, editors. Prosiding Seminar Nasional Teknologi Peternakan dan Veteriner. Bogor (Indones). Indonesian Center for Animal Research and Development. p. 681-687.

Ariyanti T. 2016. Isolasi, Karakterisasi dan pemanfaatan bakteriofaga untuk identifikasi Escherichia coli O157:H7 (Disertation). [Jakarta (Indones)]: Universitas Indonesia.

Ayscue P, Lanzas C, Ivanek R, Grohn YT. 2009. Modeling on-farm Escherichia coli O157:H7 population dynamics. Foodborne Pathol Dis. 6:461-470.

[BSN] Badan Standarisasi Nasional. 2008. Standar Nasional Indonesia Nomor 2897-2008: Tentang metode pengujian cemaran mikroba dalam daging, telur dan susu, serta hasil olahannya. Jakarta (Indones): Badan Standarisasi Nasional.

Ball HJ, Finlyerry D, Burn L, Mackie DP. 1994. Application of monoclonal antibody base on ELISAs to detect verotoxins in cattle feses. Res Vet Sci. 57:225-232.

Barrow GI, Feltham RKA. 1993. Cowan and Steel's manual for the identification of medical bacteria. 3rd ed. Cambridge (UK): United Kingdom Syndicate of the University of Cambridge.

Bonardi S, Maggia E, Bottarellia A, Pacciarinib ML, AnsuinibA, Vellinic G, Morabitod S, Capriolid A. 1999. Isolation of Verocytotoxin-producing Escherichia coli O157:H7 from cattle at slaughter in Italy. Vet Microbiol. 67:203-211.

[CDC] Center of Disease Control and Prevention. 1997. Human pathogens on the farms. Morbidity and Mortality Weekly Report. 42:258-263.

[CDC] Center of Disease Control and Prevention. 2007. Escherichia coli $\mathrm{O} 157: \mathrm{H} 7$ infection associated with drinking raw milk Washington and Oregon, November-December 2005. Morbidity and Mortality Weekly Report. 56:165-167.
[CFSPH] The Center for Food Security and Public Health. 2016. Enterohemorrhagic Escherichia coli and Other E. coli Causing Hemolytic Uremic Syndrome. [Akses Februari 03 2017]. http://www.cfsph.iastate.edu.

[DGLAH] Directorate General of Livestock and Animal Health. 2017. Statistik peternakan dan kesehatan hewan (livestock and animal health statistics). Jakarta (Indones): Directorate General of Livestock and Animal Health, Ministry of Agriculture.

Hara-Kudo Y, Ikedo M, Kodaka H, Nakagawa H, Goto K, Masuda T, Konuma H, Kojima T, Kumagai S. 2000. Selective enrichment with a resuscitation step for isolation of freeze-injured Escherichia coli $0157: \mathrm{H7}$ from foods. Appl Environ Microbiol. 66:2866-2872.

Kandau FEF. 2009. Analisis molekuler Escherichia coli serotipe O157:H7 pada air minum dalam kemasan dan isi ulang menggunakan teknik Polymerase Chain Reaction (PCR) dengan rfbE sebagai gen target. Chem Prog. 2:8-14.

Karmali MA. 1989. Infection by verotoxin producing Escherichia coli. Clinic Microbiol Rev. 2:15-38.

Karmali MA, Gannon V, Sargeant JM. 2010. Verocytotoxinproducing Escherichia coli (VTEC). Vet Microbiol. 140:360-370.

Khandaghi J, Razavilar V, Barzgari A. 2010. Isolation of Escherichia coli O157:H7 from manure fertilized farms and raw vegetables grown on it, in Tabriz city in Iran. Afr J Microbiol Res. 4:891-895.

Kompas. 2004. 11 siswa SD keracunan susu kotak. Sabtu 4 September 2004. Jakarta (Indones): Kompas Gramedia

Konowalchuk J, Speirs JL, Starvic S. 1977. Vero response to a cytotoxin of Escherichia coli. Infect Immun. 18:775779 .

Kusmiyati, Supar. 1998. Escherichia coli verotoksigenik dari anak sapi perah penderita diare. Hardjoutomo S, Darminto, Darmono, Suhardono, Bahri S, editors. Prosiding Seminar Hasil-hasil Penelitian Veteriner. Bogor (Indones): Balai Penelitian Veteriner. p. 103-108.

Marlina, Husni E, Amalinda F, Radu S, Nishibuchi M. 2009. Isolasi bakteri pathogen Escherichia coli O157:H7 pada sampel seafood dan deteksi gena flich7 secara PCR. Majalah Farmasi Indonesia. 20:73-76.

Mustika OC, Pinatih KJP, Suardana IW. 2015. Uji kepekaan Escherichia coli O157:H7 feses sapi di Kecamatan Kuta Selatan Badung Bali terhadap antibiotik. Indones Medic Vet. 4:342-350.

[OIE] Office International des Epizooties. 2008. Terrestrial manual: Verocytotoxigenic Escherichia coli. [accessed October 11th 2011]. http://www.oie.int

Pirro F, Wieler LH, Failing K, Bauerfeind R, GBaljer G. 1995. Neutralizing antibody against Shiga-like toxins from Escherichia coli in colostra and sera of cattle. Vet Microbiol. 43:131-141.

Rangel JM, Sparling PH, Crowe C, Griffin PM, Swerdlow DL. 2005. Epidemiology of Escherichia coli O157:H7 
Outbreaks, United Status, 1982-2002. Emerging Infectious Diseases. 11(4):603-609. [accessed December 6th 2016]. www,cdc.gov/eid.

Sartika RAD, Indrawani YM, Sudiarti T. 2005. Analisis mikrobiologi Escherichia coli O157:H7 pada hasil olahan hewan sapi dalam proses produksinya. Makara Kesehatan. 9:23-28.

Scheutz F, Nancy AS. 2005. Bergey's manual of systematic bacteriology. In: Garrity GM, editor. 2nd ed. Vol. Two Part B. New York (USA): Springer Publishing. p. $607-$ 613.

Stanford K, Croy D, Bach SJ, Wallins GL, Zahiroddini H, McAllister TA. 2005. Ecology of Escherichia coli O157:H7 in commercial dairies in Southern Alberta. J Dairy Sci. 88:4441-4451.

Suardana IW, Sumiarto B, dan Lukman DW. 2007. Isolasi dan identifikasi Escherichia coli O157:H7 pada daging sapi di Kabupaten Badung Provinsi Bali. J Vet. 8:16-23.

Suardana IW, Putri PJRA, Besung INK. 2016. Isolasi dan identifikasi Escherichia coli O157:H7 pada feses sapi di
Kecamatan Petang, Kabupaten Badung-Bali. Buletin Veteriner Udayana. 8:30-35.

Supar, Hirst RG, Patten BE. 1988. K-adhesins and Oserogroups of enterotoxigenic Escherichia coli in calves and piglets with diarrhoea. Proceedings of the sixth conggress federation of Asian Vet Ass. Bali (Indones). p: $479-485$.

Stringer SC, George SM, Peck MW. 2000. Thermal inactivation of Escherichia coli 0157:H7. J Appl Microbiol Symp Suppl. 88:798-898.

Synge BA. 2000. Verocytotoxin-producing Escherichia coli: a veterinary view. Symp Ser Soc Appl Microbiol. 88:31S$37 \mathrm{~S}$

Wells JG, Shipman LD, Greene KD, Sowers EG, Green JH, Cameron DN, Downes FP, Martin ML, Griffin PM, Ostroff SM, Potte ME, Tauxe RV, Wachsmuth IK. 1991. Isolation of Escherichia coli serotype O157:H7 and other shiga-like-toxin-producing $E$. coli from dairy cattle. J Clin Microbiol. 29:985-989. 